\author{
Karol Chwedczuk-Szulc \\ University of Wrocław \\ Andrzej Polus \\ University of Wrocław
}

\title{
SOCIAL CONSTRUCTIVISM AS FORECASTING MATRIX. COLLECTIVE HABITUS IN INTERNATIONAL RELATIONS
}

DOI: $10.2478 /$ ppsr-2020-0001

\begin{abstract}
Authors
Karol Chwedczuk-Szulc, Ph.D. works at the Institute of Political Science of the University of Wrocław. His main scientific interests include theory of international relations (focusing on social constructivism), EU-US comparative study (historical sociology, foreign and international policy), sociology of politics.

ORCID no. 0000-0001-6405-1024

e-mail: karol.chwedczuk-szulc@uwr.edu.pl

Andrzej Polus, $\mathrm{PhD}$, is an associate professor at the Institute of International Studies, University of Wrocław. He is an author of over 60 peer revwied publications. His major fields of research interest include: theories of international relations, othering processes, international relations in sub-Saharan Africa, and the resource course phenomenon. He has conducted field research in Angola, Botswana, Ghana, Namibia, South Africa, Tanzania, Uganda, and Zambia.
\end{abstract}

ORCID no. 0000-0002-6305-1599

e-mail: andrzej.polus@uwr.edu.pl

\begin{abstract}
Social constructivism is not among the most popular theoretical approaches used in forecasting in International Relations. The article argues that constructivism suffers from the same limitations as any other paradigm in IR, therefore, there is no reason to exclude this theory from forecasting effort. In this paper, social constructivism is perceived to offer a new conceptual framework for sound and robust projections of the future. The core of our concept is constituted by the term of collective habitus. Habitus is a relatively stable, yet mutable social structure that can enable deliberations about future. It is based on a long-term history study programme of the School of Annales, as we identify long lasting habits-like patterns of behaviours among IR actors.
\end{abstract}

Keywords: collective habitus, national habitus, forecasting, social constructivism, future's projection, zones of plausibility

What is real? How do you define real? If you're talking about what you can feel, what you can smell, what you can taste and see, then real is simply electrical signals interpreted by your brain.

Morpheus to Neo in Matrix, 1999. 


\title{
Paper's aim and structure
}

\author{
Take the red pill
}

Social constructivism is usually presented as a theoretical framework with a limited potential in forecasting. This approach is predominantly focused on understanding processes of social construction of an international "reality". In the recent wave of literature on forecasting's boundaries and limitations in International Relations (IR), social constructivism is presented as a theory revealing how the "knowledge of the future is produced and used" (Stackelberg and McDowell 2015: 26-27) and "has most to gain from honing its own conception of causality" (Meyer 2011: 687). This paper challenges the argumentation that social constructivism cannot offer a robust epistemological perspective for forecasting in IR. We also argue that, through the concept of collective habitus, it is possible to pursue a form of forecasting, that we call "projections" of the future.

The article's first section presents the current state of the art in forecasting in IR. Next, we synthetically present the core points of our idea of whether and how a social constructivist approach can be useful in forecasting. The third section is devoted to the main theoretical concept - collective habitus - which allows us ruminations about the zones of plausible future behaviours of IR actors. The fourth section concludes the article.

\section{The current state of art in terms of forecasting in IR}

\section{What if I told you that IR is the Ben Jonson of the social sciences'?}

It is common knowledge that in the social sciences multiple knowledge systems co-exist at the same time. There is a constant debate about the very existence of regularities and laws in the social world and possible ways of accessing these laws/truths. While recognizing the multiplicity of approaches, we also recognize that it is the positivist philosophy of science that has predominantly shaped the discussion about the IR as a field of scientific activity. Discussion between representatives of postmodern approaches and positivists brought questions about the objectives and objectivity of scientific activity in IR into the discourse. We accept that any knowledge system is by definition a situated knowledge and no claims can be formulated without a context. Nevertheless, both positivists and postmodernists accept the notion that certain ideas about the future are necessary in the social sciences. The core difference lies in the character, usefulness and the ways of obtaining such a knowledge.

International Relations is not unique, since in the social sciences, there always has been sorrow that a predictive function of science is hardly fulfilled. One can distinguish at least three epistemological orientations which structured both the developments of the social sciences and the ways of thinking about the future. The first-behavioural/positivist approach, most popular in the 1960s, is based on the assumption that there are discoverable regularities in social life, which can be measured and "expressed in generalizations or theories with explanatory and predictive value" (Mazuri 1999: 171). In political science, this

1 Ken Booth described International Relations in the mid-1990s as an academic discipline on steroids - the Ben Johnson of Social Sciences, Ken Booth, Dare not to Know: International Relations Theory versus the Future, in: „International Relations Theory Today”, ed. K. Booth, S. Smith, Polity Press, Oxford 1995, p. 331-332. 
orientation was developed by, among others, David Easton and Harold Lasswell (Lasswell 1971: 53-55). Behaviouralism is usually correlated with the notion of the "tyranny of the method over the subject" and fascination with statistically demonstrated correlations (Gaddis 1992-93: 12-13). American political science "was founded on these traditions of rigorous method, but in ways that recognised the exigencies of context, empirical fuzziness, and the mediating role of history, culture, and agency". The reminiscences of behaviouralism can be currently found in game theory, with its focus on decision-making situations, and the modelling of the strategically motivated decisions (de Mesquita 2010). This way of theorising together with realist and neo-realist approaches in international relations, also dominated strategic studies during the Cold War (Freedman 2009: 389-394). On the other hand, classical realism is usually presented as a "prescriptive" International Relations' theory. Nevertheless, its praxeological dimension should not be equated with the fulfilment of the theory's predictive function. Barkin (2009: 233-246) argued convincingly that "classical realist theory is incompatible with the epistemological assumption that international relations is fundamentally predictable". Structural realists (as any structural theorist) also suffered from the inability of complex explanation of the changes that occurred in the international environment after World War II (Gilpin 1999: 145-152).

A different approach to forecasting is taken by evolutionists, who assume that linear evolution is a natural component of social processes. The notion of an evolutionary nature of social interactions is ontological. One of the most popular evolutionist forecast techniques is extrapolation of trends. This proposition is based on the Hegelian dialectical approach to history and has been used by, among others, Karl Marx in Capital: Critique of Political Economy, and more recently by Francis Fukuyama in The End of History. Dialectic perception of the relation between major "casual forces" in social interactions had multiple consequences-ontological, epistemological and methodological. It has paved a way for alternative approaches in IR. The interplay of evolutionary and behavioural orientation has produced various methodological syntheses such as evolutionary modelling or artificial intelligence simulations. Together with game theory and trend extrapolations, these are among the most popular forecast techniques in IR and security studies. On the other hand, evolutionary approaches are also mirrored in the functionalist and neofunctionalist paradigms.

Interestingly, discussions about the basic nature of the universe were also taking place in natural sciences. In physics, the debate was centred around the nature of certainty and probability. It was embodied in a famous discussion between Niels Bohr and Albert Einstein. Bohr argued that the act of "measurement" creates a situation when a protocol is situated in a certain place, which implies uncertainty as an ontological feature of the universe. Nevertheless, the Heisenberg uncertainty principle allows forecasting in quantum mechanics. A similar argument is, to a certain degree, reflected in the social sciences. For example in a statement that perception is prior to the courses of events, or even more, that contextualisations and socialisation processes shape the social phenomena. We argue that, while the transplantation of the "uncertainty principle" to the social sciences is not possible, we can still identify relatively stable, socially constructed structures. It is possible that their features will be changed by the fact that we are discussing them. These structures are obviously changeable, but are also more stable than other ideational structures. The awareness of their existence and relative durability provides a foundation for short 
term ruminations about the future. We argue that a group habitus defined in the paper can provide such a foundation.

The third epistemological orientation used for predictions is a structuralist approach, under different forms. It assumes the existence of directly unobservable social structures influencing social interactions. In IR, the most prominent and widely criticized representative of this orientation was Kenneth Waltz. In sociology, Anthony Giddens introduced the idea of the "duality of structures" (for example: micro/macro, or material/ideational). The reproduction of social systems due to the constant mutually constructive interactions between agents and structures is a core premise of his structuration theory. This very assumption is also the backbone of social constructivism in IR.

The most common method of forecasting in IR is, as already mentioned, a linear extrapolation of past events, experiences and processes into the future. In the 1960s and 1970s, RAND Corporation popularised heuristic forecast methods such as the Delphi method or scenario building. The Committee on Forecasting Future Disruptive Technologies of the US National Research Council has distinguished between judgmental or intuitive methods, extrapolation and trend analysis, models, scenarios and simulation as major "categories" of forecast methods (National Research Council 2010: 3). The major debate on forecasting in IR took place at the turn of the 1970s in the "International Studies Quarterly" (Freeman and Job 1979: 113-143; Vincent 1980: 450-454; Choucri 1979: 145-149). The conclusion of this debate was not optimistic, since it emphasised the terminological chaos in forecasting. An almost four decade old statement about forecasting in IR is still valid today - we lack intersubjectively accepted research categories, and future forecasting is the least fulfilled function of IR. This observation is correlated with the dominance of a positivist epistemology in the discourse on forecasting in IR. Hence the pressure on creation of a "technically useful knowledge, knowledge that enhances human capacity to make predictions" (Ashley 1984: 249).

The controversies over the scientific character of International Relations erupted after the collapse of the Soviet Union and were facilitated by an obvious failure of foreseeing the most important international event after 1945 - the end of the Cold War (Booth 1995: 331-332). This situation directed scholarly attention to the need for creating an epistemologically coherent project in IR. It resulted in a swing towards a theoretical reflection on the discipline evolution, and facilitated "interparadigm debates" (Waever, 1996).

While some sociologists in the 1980s put multidimensional change and the impossibility of finding regularities in the centre of their research projects, IR was preoccupied with a desperate search for generalisations which could provide a basis for anticipating the future and possibly introducing modelling into the mainstream IR discourse. It is obvious that the presumptive agreement on a specific vision of international reality (however unimaginable) would be synonymous with a top-down determination of "the laws" governing the multidimensional interactions in an international environment. Consequently, since it is impossible to carry out experiments with perfect repeatability in the social sciences, each event or process should be perceived as a unique phenomenon. This leads to the conclusion that generalisations are either impossible or banal. Therefore, the lack of general laws makes deductive reasoning impossible in IR.

On one hand, creating a general law in IR would open up a possibility of forecasting events that can be subsumed under a given generalisation. On the other, we have at our disposal multiple theoretical axioms in IR, serving as quasi-generalizations and allowing 
limited deductive reasoning ${ }^{2}$. Kenneth Waltz's "logic of international anarchy" is a good example of such a generalisation. This, however, leads to a situation in which the facts and processes that are to be forecasted are selected and interpreted by a quasi-generalization, which finally may make the falsification of quasi-generalisations more difficult.

Another example of quasi-generalisations are historical generalisations, based on long-term observations and analogies. Arnold Joseph Toynbee's "law of challenge and response" (explaining how civilisations rise and fall) or the democratic peace theory, are examples of this kind of generalisation in IR (Lee Ray 1998: 27-46). In other words, any claim about the nature of international relations is correlated with a theoretical assumption accepted a priori. We decided that the most reasonable solution, while considering the forecasting possibilities in IR, would be an adoption of the widest possible ontology. This is represented by a social constructivist statement that the world (and international relations) is socially constructed. Thus, we assume that the processes of creation of various international or domestic perceptions and practices form the basis for forecasting in IR. The existence of collective (group) habitus ${ }^{3}$ should then be seen as a quasi-generalisation, allowing considerations about the near future ${ }^{4}$.

In the social sciences, forecasting is usually associated with "predictions based on knowledge of past behaviour" ("Symposium on Prediction in the Social Sciences" 1995: 1520-1626; Doran 1999: 11). Irrespective of forecast techniques we use, the future is linked with the past. As Giddens noticed, possible futures are reflexively constructed in the present (Giddens 2007: 15-60). As we noted above, many scholars have grappled with the issue of uncertainty, and how to manage it in the social science, both theoretically and practically. We argue that the concept of collective habitus is a useful and missing piece in debates about constructivism's potential in forecasting. It as a theoretical concept, allowing scholars operating within the constructivism paradigm to construct more robust and sound forecasts. As noted by Charles Doran, "A complete forecast will express 'what' is likely to occur, 'when' it will occur, and 'how' it will occur" (Doran 1999: 11). Most forecasts in the social sciences, however, are only partial, mentioning possible visions of the future, or they focus on a long term perspective (Friedman 2009) and should rather be considered as political fiction than forecasts in an academic sense.

Through the very focus on the habitus, we do not intend to create even more confusion in IR, by weighing in with another term, a derivative of the already existing ones. We argue that the collective habitus is the most stable social structure and its relative lack of mutability provides a base for short and mid-term forecasting. Therefore, we are challenging the established claim about the limited forecasting potential of social constructivism (Barnett 2006: 261-262). This claim stems from the assertion that social constructivism does not ask questions about regularities in social life and is rather past-oriented. In our view, if we are able to identify and understand stable socially constructed structures, we can recognise zones of plausibilities of social life. This, in turn, would allow as to take on

2 The reasoning is "limited”, because deduction is true only if the general law is true, and we usually use theoretical axioms or historical generalizations which imply that our reasoning, although procedurally correct, might be false.

3 We accepted „habiti” as a plural form of the word „habitus”.

4 For that reason the text can be seen as part of a trend, where selected sociological approaches and research categories are transplanted into IR, M. Albert, B. Buzan, M. Zürn (eds.) Bringing Sociology to International Relations. World Politics as Differentiation Theory, Cambridge, Cambridge University Press 2013. 
the task of prediction. We are fully aware that our paper might be perceived as a part of the "anything goes" narrative in IR (Jarvis 2000: 88): however, the very concept of habitus synthesises dialectical distinction between agency and structures in social constructivism. Moreover, the text can be seen as a "re-discovery" of the $19^{\text {th }}$ century term and its naive adjustment to the $21^{\text {st }}$ century debate about the predictive function of the social sciences. Conversely, we recognize the very presence of the habitus concept in IR literature (McCourt 2016: 481) and a cyclical return of various research categories to the mainstream theoretical discourse in IR. However, the aim of our proposal is to conceptualise the collective habitus in terms of forecasting in IR. Additionally, we see an interpretative potential for the habitus concept in debates on the structuration process and the creation of a clearer distinction between risks and uncertainties. In fact, the definition of the "zones of plausibilities", presented below, partially removes uncertainty from the ruminations about the short term forecasts. To sum up, we do not rediscover the very concept of Bordieu's habitus, the innovation of our approach lies in using it as a tool in projections of the future.

\section{Social constructivism and projecting the future}

What if there is no spoon...

Constructivism in its "mainstream" version does not deal with the philosophical question of ontology. Instead, the core axiom of this approach is formed in a tautological manner - that the social world is socially constructed. Therefore, it is rather a meta-theory posing "why" and "how" questions, not "what" (Merton 1968). It focuses on the processes of meanings and intersubjective knowledge creation. As Giddens argues, the very understanding of how the meaning and actors' dispositions are created, should be of central importance for the "forecast programme" (Giddens 2007: 15-60).

Nevertheless, while considering the predicting potential of social constructivism, we have to re-define the concept of forecasting itself. The dubiousness of forecasting or prediction, from the perspective of social constructivism, comes from the nature of the social sciences. If we define forecasting as a prediction based on knowledge of past behaviours and actors' dispositions to act, we have to admit that it is impossible to obtain complete knowledge in this regard. Additionally, if the world is socially constructed, then understanding of the past is also generated post factum, which might be correlated with ideas, mentioned above, that humans are future orientated entities. We argue that the limits of constructivist forecasting are similar to the limitations of other IR theories. However, the difference, and simultaneously the advantage of social constructivism, lies in the fact that constructivism accepts these limitations and incorporates them into projections of the future. Therefore, we propose to use the term "projection" instead of "forecast", to differentiate it from traditional approaches ${ }^{5}$.

Every attempt of prediction is also a social practice itself. Therefore, it is impossible to assume a detached position of objectivity, understood in rationalist categories. Hence the question is: can social constructivism bring an added value into considerations about the future since it is a theory focusing on the past and present? It does not matter if we operate

5 Special thanks should be offered to prof. Patrick Thaddeus Jackson from the American University for coming up with the word "projection" of the future. 
within the critical or lingual version of social constructivism, it underlines strongly that every phenomenon of social life can be only analysed through the lenses of a given Zeitgeist. In other words, only a description and understanding of concrete circumstances in a given time and space enables understanding of actors' behaviours. We argue that such a perspective can make predicting more down to earth and help assert the accuracy of a projection.

The synthetic summary of our proposal in terms of forecasting within the social constructivist paradigm is presented below:

- The central epistemological term which allows a constructivist projection is a group/ collective habitus ${ }^{6}$ understood roughly as a group mindset ${ }^{7}$ towards certain behaviours. The main elements included in this concept are among others: distinctive features of the group, dispositions, social roles, values, collective biography, socio-psychological profiles of decision-makers, and the structure of external environment ${ }^{8}$. All of these elements are perceived in historical and dynamic perspectives. It is not an exhaustive catalogue of elements, because it is impossible to create such a catalogue. Each case has to be analysed individually, and will have its own catalogue of relevant elements. Identification and detailed description of given factors is predominately aimed at understanding possible dispositions and behaviours of given actors. This implies that one has to determine what type of actions, according to its group habitus, the actor is likely to undertake in any given circumstances, and which behaviours are excluded from the actor's toolbox. Such a set of behaviours, limited by plausible and implausible behaviours, constitutes the basis for a prediction. This concept is based on the social constructivist claim that if something is unimaginable in a certain time and space, then it could not possibly exist.

- Research on a collective habitus has no methodological limitations, as long as the method serves its purpose. There is no contradiction between broadly understood positivist methodology and social constructivism, because the latter makes statements about ontology and epistemology, not methodology ${ }^{9}$. Ultimately, positivism is also a social construct. Social constructivist epistemology does not exclude the requirement of intersubjectivity as sine qua non of modern science. The nature of knowledge is not objective. Thanks to a commonly known methodology, it is intersubjective and may be conveyed and understood by other members of a given epistemic community (Adler and Haas 1992: 367-390). In other words, methodology serves as a "language" that allows IR scholars to communicate. Therefore, we pos-

6 This concept is based on the idea of sociologist Norbert Elias, who used a notion of „national habitus" towards Germans. This group habitus is analysed in a historical perspective, as it is a relatively stable social structure, changing in a gradual, evolutional manner. Vide: N. Elias, The Civilizing Process, New York, Urizen Books 1978.

7 We understand mindset here as collective mental dispositions, presumptions about the world which are stable and slowly changing over time.

8 We include external environment as an element influencing collective habitus, as later in a paper we differentiate between what we call essential and contextual habitus. We are convinced that a broadly understood context in which a given group functions is important and shapes the group's habitus.

9 Social constructivist epistemology describes the character of acquired knowledge and points out the main research field (social construction of meanings), but is not at odds with the positivist methodology that can be used to research social perception. In this perspective, any given methodology can be treated as a neutral tool that produces information 
tulate that scholars should always strive for intersubjectivity. We are convinced that even the most unique method can be "translated" into an intersubjective "language" so that it could be included into the debate.

- Dispositions derived from a group habitus create a zone of plausibility within which the projection is designed. The forecast does not predict certain tactics, policies or events, it describes the space of possible developments, a set of possible behaviours, limited by threshold dispositions (Picture 1). As expressed above, threshold dispositions describe behaviours which seem to be completely implausible or very plausible, given the knowledge on actors' collective habitus.

Graphic 1. Zones of plausibility.

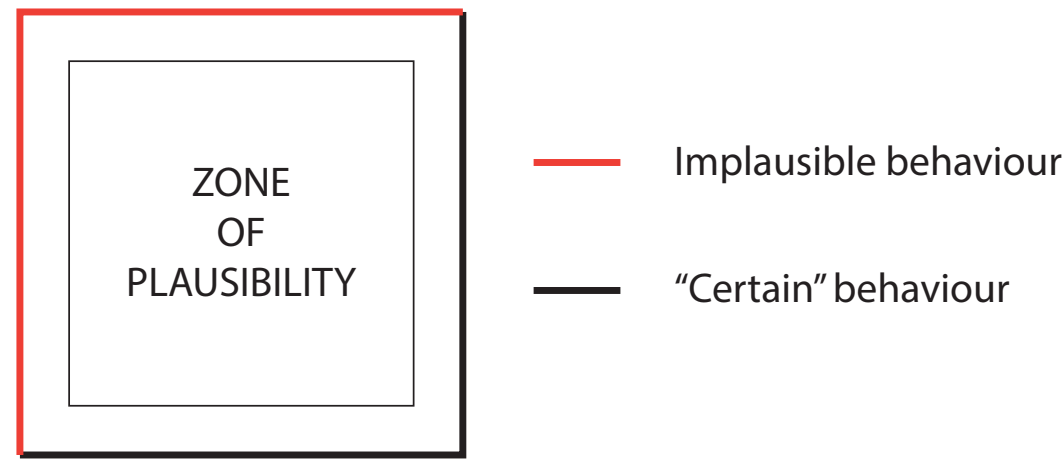

- Each projection is limited by a given space, time and accessible knowledge. It has to be taken into account that there are "unknown unknowns" that can become game-changers. Therefore, the prediction has to be not only embedded in the context, but has to be open to "unknown unknowns" as well as to "known unknowns"10.

- Predicting is a social practice and is involved in a symbolic interaction, co-creating a social reality. As such, it is not only influenced by the social structure but also exerts influence on the subject of prognosis (self-fulfilling prophecy, path dependence, mechanisms of reproduction).

The conceptualization presented above is a general one and does not fulfil the rigorous rules of commonly accepted scientific forecasting in the social sciences. That is why the word "projection" seems to describe the concept more adequately -it does not aspire to the ideal of absolute objectivity. It may also be problematic to determine which and how far-reaching historical strands should be taken into account while studying a given group habitus. One of possible solutions could be an agent-structure analysis. Understanding both the ideational and material basis of a collective actor ${ }^{11}$ and its reciprocal relations

10 These are phrases taken from a famous dictum by Donald Rumsfeld: „Reports that say that something hasn't happened are always interesting to me, because as we know, there are known knowns; there are things we know we know. We also know there are known unknowns; that is to say we know there are some things we do not know. But there are also unknown unknowns - the ones we don't know we don't know. And if one looks throughout the history of our country and other free countries, it is the latter category that tend to be the difficult ones". DoD News Briefing - Secretary Rumsfeld and Gen. Myers, http:// www.defense.gov/transcripts/ (30.01.2015).

11 By the phrase of „material basis of collective actor” we mean a simple fact that „materiality” exists (i.e. oil, nuclear weapon, oceans etc.). But we do not reify it. Material basis is important only as an object of social perception and meaning construction. 
with structure, may result in a better understanding of a collective habitus, ergo defining its dispositions and viable behaviour. In case of prediction in IR, the main aim of the researcher should be understanding social practices and the process of intersubjective meanings' construction. These processes, being an immaterial structure of the IR system, are uncertainty-level reducers, as they provide a framework for communication between international actors (Hopf 1998: 171-200). The predictability of interactions between actors within the structure (and structures within a broader structure), builds up the robustness of predictions about future developments.

\section{The concept of Collective Habitus}

We're willing to wipe the slate clean, give you a fresh start

The core concept of our perspective is collective habitus. Pierre Bourdieu is most often perceived as an author of this very concept. However, Wacquant (2016: 65) argues that the concept of habits can be traced back to Aristotle's notion of hexis and to the writings of Thomas Aquinas, Emile Durkheim (who speaks of Christian habitus) Thorstein Veblen (who mentions 'predatory mental habitus'). The existence of the habitus concept in Anglophone philosophy was presented by Moran (2011: 53-59). Bourdieu defined habitus as:

[...] systems of durable, transposable dispositions, structured structures predisposed to function as structuring structures, that is, as principles which generate and organize practices and representations that can be objectively adapted to their outcomes without presupposing a conscious aiming at ends or an express mastery of the operations necessary in order to attain them. Objectively "regulated" and "regular" without being in any way the product of obedience to rules, they can be collectively orchestrated without being the product of the organizing action of a conductor (Bourdieu 1992: 53).

Although this seems to be the most commonly cited definition of habitus, we have a strong impression that it requires a "translation into English", as it is incomprehensible in this form. As we understand this definition, the habitus is:

Principles, creating a system of durable dispositions and structures, responsible for organised, semi-conscious, or unconscious practices. These principles and rules are seen as common and are treated as objective. The principles are not orchestrated by any given actor, but are collectively produced and reproduced. Adherence to the rules comes from their perceived objectivity.

We are, of course, aware of the fact that the whole conception of Bourdieu includes also the concepts of field, cultural capital and doxa. Nevertheless the aim of the article is to explore the potential of habitus itself.

The most important features of habitus defined by Bourdieu are the normalisation and structuring properties of habitus. Normalisation makes the set of rules called habitus "objective", which means that it orchestrates behaviours through the mechanism of dispositions. Dispositions are deeply rooted in the group's way of approaching other so- 
cial actors and they can be claimed to be unaware or semi-conscious at best ${ }^{12}$. As such, one's behaviour stemming from habitus is structured, and to some extent determined ${ }^{13}$ by the values, views and attitudes that one has internalised. This constitutes the second most important element of the habitus: "structuring structures". The habitus is not only a property of an individual, but of a given social system - it is created and reproduced only within the group (or between groups), in the process of constant interactions between its members. The social system is structured by the habitus. Therefore the habitus is an immaterial meta-structure capable of "structuring other structures". We are aware that this is a tautological statement, just like the constructivist statement about the social construction of the social world. Nevertheless, it is a founding axiom of the habitus concept. We do not try to introduce a "super-structure" of human behaviour which, when discovered, will serve as a law-like generalisation allowing a precise prediction.

In principle, we agree with Andreas Pickel's statement that the habitus is a firmly social and emergent concept, created within any social system; the same understanding of habitus was also presented by McCourt (2016: 479). Therefore, it is justified to use it for the description of groups rather than individuals (Pickel 2005: 437-461). Habitus is not a static, given (reified) structure, but a process that is being constantly reproduced, reassured and (in the long term) reshaped through interactions between the elements of a social system. It has a strictly reciprocal character, on the continuum of top-down/bottom-up interactions. It means that not only does the habitus deliver a structure for interactions between agents, but agents, via their actions, can influence the habitus, changing its character. Wacquant (2016: 66) clarifies the concept of habitus by analogy to Chomsky's 'generative grammar', "which enables speakers proficient in a given language to produce proper speech acts unthinkingly according to shared rules in inventive yet predictable way".

As noted by McCourt "terms like node and habitus are each designed to grasp the connections between position (where one is located in social relations) and disposition (what actors consequently want to do and feel the necessity to do.)" (McCourt 2016: 481). However, we must not forget that the interactions shaping habiti take place not only vertically, as described above, but also horizontally. It means that different habiti at the same level, e.g. national habiti, shape each other through the process of interaction. One example of this process can be cultural diffusion understood as a spread, exchange and hybridisation of cultural items, resulting in changed practices (Gilardi 2012: 453-477).

Even though the habitus changes over time, it is a relatively stable structure as it is rarely the case when the whole set of practices and dispositions changes within a very short period of time. A war changing the whole social structure of a given society would be one example of a rapid change. In modern times, however, a social structure changes most often through processes like migration, technological development, political or economic transformations. Such changes are evolutionary and gradual in essence. This is how the collective habitus, meaning the habiti in a macro-sociological scale (nations, various international communities or even civilizations), undergoes changes. This problem was

12 As an example of these mechanisms, one can think of Russian reactions to even the slightest changes in Russia's neighbourhood. Everything that does not coincide with a pro-Russian political course is met with a decisive, even aggressive Russian reaction. The Russian invasions of Georgia in 2008 and of Ukraine in 2014 being two examples.

13 Determined in the sense that habitus' dispositions constitute a "toolbox" from which an actor can choose its behaviours, rarely looking for a tool from outside of the box. 
stressed by Lahire (2003: 339) who noted that "dispositions differ from one another in stability and strength [...] the relative strength or weakness of dispositions depends in part on the frequency with which they are actualised". National habitus is one of most often "actualised" not only due to the fact of the constant process of interactions in the international environment, but also by performative and formal dimensions of the state while relating to its citizens. As Pickel points out, each social system creates its own habitus: from families, through villages, up to cities, regions, and countries. Naturally, the stability of a given collective habitus will vary between groups. Pickel gives an example of a demonstration, where the habitus can be formed and changed quickly (Pickel 2005: 477) ${ }^{14}$. However, in the case of macro-scale groups like nations, such a change in habitus is rarely possible.

To some extent, it is a matter of sheer size - it is much harder to manage and alter a big social group such as a nation, than a group of a size of a family, or an ad hoc created group like a demonstration or a Facebook group. In this sense, we can talk of a "depth of habitus". By this notion we understand the scope and profoundness of collective habitus' influence on a given mindset. For example, the state or church will have more powerful and long-lasting tools to shape the habitus than a Facebook group. First of all, states or churches have much more members who are carriers and reproducers of a certain habitus. The relations between them are strong, thus supporting the durability of the habitus. A Facebook group, in turn, is usually created ad hoc, and has a limited number of members who are not committed to the group with all their potential. Therefore, the collective habitus of the latter group is much more prone to changes or even drastic alterations.

At this point, one can already see that our conceptualisation of collective habitus bears traits of a structural theory. Collective habitus, according to the definition of Pierre Bordieu, is indeed an element that produces other social structures. But yet, to stress it once again, we avoid ahistoricism and reification of the structure. Every analysis of this concept has to be contextual and has to take into account the fact that the habitus is stable when compared with other social structures, but still dynamic by itself. In other words, large social groups' collective habiti are usually subject to change in a long-term perspective. From among other social structures such as norms, values or patterns of behaviour, habitus is the most durable one. This very feature of habitus provides us with a relative stability which is necessary for future anticipation.

Collective habitus can be understood as a context, or as the main current of the river, to use a metaphor, with which an individual goes. The main current (habitus) provides water for other streams, like norms, values, attitudes, roles - tools that can be used for conscious identity building (Hitlin 2003). Habitus also powers a stream of habits. A habit is an unconscious disposition, a tendency to act (behave) in a certain way ${ }^{15}$. As Ted Hopf

14 As a good example, we can use the concert organized annually in Poland, called Woodstock Festival. It obviously refers to the famous Woodstock festival from 1969. What is unique about the Polish festival, is a set of principles that participants of the festival follow - voluntarily and mostly only during the festival, not in their every-day life. To avoid going too much into details, let us just summarize, that participants evince behaviour that requires very high level of social trust, while Polish society has one with the lowest levels of social trust in Europe. Vide: A. Grześkowiak (2014), ,Assessment of Interpersonal Trust of Poles by the Principle Components Analysis and Log-Linear Modeling', Econometrics 1(43): 74-86.

15 We are grateful to prof. Dorota Wiszejko-Wierzbicka from the University of Social Sciences and Humanities in Warsaw for scholarly consultations, which let us better understand the relation between values, norms, attitudes and identity. We also thank her for sharing with us with the metaphor of the river in reference to the terms collective habitus. 
argues, resting his statement on the work of modern neuropsychology: "Habits are unintentional, unconscious, involuntary, and effortless, that is, they do not consume limited cognitive processing capacity. Controlled processes are intentional and effortful" (Hopf 2010: 541). He describes a habit as automatic and unreflective, offering stereotype as an example. Such an understanding of a habit is very close to what is known in psychology as heuristics of judgment and decision making (See: Lewis 2008: 43). We argue, after Weber (as cited in Hopf 2010: 540), that habits, practiced over a long, historical perspective, become a dispositional part of habitus. But it is important to remember that habitus is not only a set of habits. It is rather, as put in the definition presented earlier, a set of principles and schemes internalised by individuals in the process of socialization (Bourdieu 1990: 13). These rules and principles orchestrate our perception and behaviour.

It is necessary to stress that habitus may have many dimensions, overlapping each other; therefore habitus is a multilevel and multidimensional concept. We can manifest different dimensions of habitus in specific situations, e.g. with our family, in our work environment, city, nation, or even broader, religion or cultural circle. Because the concept of habitus is multilevel indeed, there is no conflict between different levels of different habiti. At the same time, it does not prevent potential conflicts between these dimensions, as they simply represent different spheres of life.

The issue of multidimensionality of habitus is connected with a difference between, what we call, essential and contextual habiti ${ }^{16}$. Essential habitus refers to a set of dispositions that any given actor has per se, i.e. the habitus indigenous to the group, not linked directly to any external subjects. Contextual habitus in turn is a habitus that is externalised in interactions with other actors. Usually, the contextual habitus is embraced as part of a broader habitus. For example, we can speak of a German habitus per se, but we can also speak of a German habitus in relations to its partners in the European Union. In this case, a European habitus would serve as a meta-habitus, mediating in relations between German and, let us say, French habitus. Of course both dimensions of habitus (essential and contextual) are directly related, which should be described individually for every setup of relations, whether bilateral (e.g. German-French) or multilateral (within the EU).

At this point the Reader may pose a question: what about the relation between the habitus and identity, as these concepts sound synonymous? We are convinced that these terms do not refer to the same subject, although they remain closely connected. The first and most important difference lies in a fact that identity is a conscious self-definition of a group or an individual. It is hard to think of any national identity that is unrealised. As Henri Tajfel puts it, the collective self is always aware and it is subject to individual choice to some extent. The aim of this choice is to strengthen a positive self-evaluation; therefore an individual chooses groups offering her/him positive reinforcement of the self (Tajfel 1968:68). The choice is not limited only to one group and an individual can refer and belong to many groups, which will be her/his in-groups. The more collective the culture, the more reference groups may be selected by an individual (Triandis as cited in Wojciszke, Jarymowicz 1999: 127-128). Habitus, in turn, as mentioned before, is mostly an unreflective and uncontrolled part of social life. Thus, habitus is not subject to a free, conscious choice of an individual or a group.

16 We want to thank again prof. Patrick Thaddeus Jackson from the American University, for bringing to us this differentiation. 
If identity is a conscious realisation of one's own sense of belonging, it is also relatively easier to change (though not necessarily easy), via an individual/group decision. We can decide to switch our political identity, religions, regional identities and even national belonging and attachment to a given national community. Obviously, in such a case, in our striving for a coherent worldview, we would start changing our behaviours and habits according to our changing identity. Gradually, habitus would also start to change. We are semi-aware of our habitus at best, therefore it demands a long and complicated endeavour of self-reflectiveness to change habitus (Hopf 2010: 555). Habitus, being an uncontrolled element of society, does not entirely depend on our conscious decisions. In relation to identity, habitus is much more stable, and takes much more time to change. In order to describe this relation, we can graphically present it as a river, a metaphor already mentioned above. Identity is very important (wide), but still just a creek, flowing into a main river-habitus. A change in identity will of course influence the stream of the river, but will not change its main course. Naturally, the river may also influence the creek, by the mechanism of backwater. Therefore, the creek and river are not equally strong, but mutually constitutive.

Understanding the relation between the identity and the habitus is essential for understanding the approach we theorise in this article. The character of this relation can be explained using the notions from Freud's psychoanalysis. Here, the habitus is ego and the identity is a superego. Habitus is the way an individual or group behave; their practices, the manner in which they realise basic needs and desires (id). Identity (superego) are the values and rules internalised by an actor, seen as an ultimate goal; a perfection. It sublimates the urges and needs, in effect we receive the habitus (ego), a set of dispositions and practices, mediated through socially accepted norms. Therefore, the aim of the habitus is to fulfil actor's needs in a socially accepted way. We argue that by discovering a possibly detailed description of habitus, we can obtain a social structure stable enough to make plausible projections.

\section{Conclusion}

\section{Dodge this!}

It is puzzling that social constructivism has not been employed in international forecasting and simulations after visible "interpretivist and the sociological turns in the social sciences" and IR (Guzzini 2000). This situation can partly be explained by the fact that some of the leading constructivist theorists defined this approach as predominantly orientated towards understanding of past and present processes (Adler 1997: 319-363). We challenge this narrative and claim that a re-interpretation of history from the perspective of the collective habitus can enable projections into the future. Even more so, the awareness of the existence of double hermeneutic should be perceived as the upside of constructivism when compared with other visions of forecasting within IR.

In order to allow ruminations about the future, we have re-introduced the concept of group habitus. The habitus, defined as a social structure that re-creates and sustains durable group dispositions (habits) towards certain behaviours, is the cornerstone of our idea. We do not deny mutual constructions of structures and agents operating in an international environment, and we do emphasise that habitus is also prone to changes. Despite 
the fact that any social group has a habitus, we offer to focus on national habiti, which are relatively stable structures, as it is rarely the case that the national habitus would change within a short period of time. This relative stability provides us with a basis, giving opportunity to discuss certain dispositions towards the most and the least plausible actions, which can be interpreted as the zone of plausibility of our projection.

Since forecasting is a social practice, every epistemic community aiming at predicting the future has its own habitus which influences its ways of reasoning. The most obvious problem here would be the impossibility of avoidance of double hermeneutic. In other words, we function in different groups, with different collective habiti as well. This fact influences every social practice we take part in, including research activity, like projecting the future. Therefore, every researcher, being a part of certain social group or epistemic community, is not free of their influence and agenda setting. When we project the future, it is probable that we will project not only the plausibilities, but also our expectations and ideas. It is important to bear that in mind in order to be able to adhere to the requirement of intersubjectivity and not to forget the possibility of self-fulfilling prophecies.

\section{References}

Acharya, Amitav and Barry Buzan (2010), 'Why is there non-Western international relations theory? An introduction', in Amitav Acharya and Barry Buzan, eds. Non-Western International Relations Theory: Perspectives On and Beyond Asia. Politics in Asia, 1-25, London and New York: Routledge.

Ashley, Richard K. (Spring 1984) 'The Poverty of Neorealism', International Organization, 38, (2): 225-286.

Adler, Emanuel and Petert M. Haas (1992), 'Conclusion: Epistemic Communities, World Order, and the Creation of a Reflective Research Program', International Organization, 46(1): 367-390.

Adler, Emanuel (1997), 'Seizing the Middle Ground: Constructivism in World Politics', European Journal of International Relations 3(3): 319-363.

Albert, Mathias, Barry Buzan and Micheal Michael, eds. (2013) Bringing Sociology to International Relations. World Politics as Differentiation Theory, Cambridge: Cambridge University Press.

Alvesson, Mats and Kaj Sköldberg (2013), Reflexive Methodology: New Vistas for Qualitative Research, London, Los Angeles: Sage Publications.

Banks, Christopher P. and John C. Blakeman (2012), The U.S. Supreme Court and New Federalism: From the Rehnquist to the Roberts Court, Lanham: Rowman \& Littlefield Publishers.

Barnett, Michael (2006), 'Social Constructivism', in John Byalis and Steve Smith, eds. The Glozbalization of World Politics. An Introduction to international relations,148-164, Oxford and New York: Oxford University Press.

Barkin Samuel (2009), 'Realism, Prediction, and Foreign Policy', Foreign Policy Analysis, 5: 233-246.

Bauman, Zygmunt (2006), 'Płynna nowoczesność', Kraków: Wydawnictwo Literackie.

Beck, Ulrich (1992), Risk Society: Towards a New Modernity, Sage: New Delhi.

Beck, Ulrich (2006), The Cosmopolitan Vision, Cambridge: Polity Press. 
Beeman, Richard R., Stephen Botein, Edward C. Carter, eds. (1987) Beyond Confederation: Origins of the Constitution and American National Identity, Chapel Hill: University of North Carolina Press 1987.

Blei, David M., Andrew Y. Ng and Michael L. (2003), 'Latent Dirichlet Allocation', Journal of Machine Learning Research 3(3):993-1022.

Booth, Ken (1995), 'Dare not to Know: International Relations Theory versus the Future', in Ken Booth and Steve Smith, eds. International Relations Theory Today Oxford: Polity Press.

Bourdieu, Pierre (1984), Distinction: a social critique of the judgement of taste, Cambridge, MA: Harvard University Press.

Bourdieu, Pierre (1990), In Other Words: Essays Towards a Reflexive Sociology, Palo Alto: Stanford University Press.

Bourdieu, Pierre (1992), The Logic of Practice, Palo Alto: Stanford University Press.

Burgess, Michael (2000), Federalism and the European Union: The Building of Europe, 1950-2000, London and New York: Routledge.

Ceruti, Furio and Sonia Lucarelli, eds. (2011)The Search for a European Identity: Values, Policies and Legitimacy of the European Union, London and New York: Routledge.

Checkel, Jeffrey T. and Peter J. Katzenstein, eds. (2009), European Identity, Cambridge: Cambridge University Press.

Choucri, Nazli (1979), 'Comments on “Scientific Forecasts in International Relations', International Studies Quarterly 23(1): 145-149.

Choucri, Nazli (1974), Forecasting in International Relations: Problems and Prospects, International Interactions 1: 63-86.

Christopoulos, Dimitrios C. (2010), 'Peer Esteem Snowballing: A methodology for expert surveys', European Commission, available athttp://ec.europa.eu/ (13 October,2015).

Chwedczuk-Szulc, Karol and Andrzej Polus (2015), 'Konstruktywizm społeczny a prognozowanie w stosunkach międzynarodowych', in Elżbieta Stadtmüller and Łukasz Fijałkowski, eds. Normy, wartości i instytucje we współczesnych stosunkach międzynarodowych", Warszawa: Rambler.

Dijk, van Teun A. (2000), On the analysis of parliamentary debates on immigration, in Martin Reisigl and Ruth Wodak, eds., The semiotics of racism. Approaches to critical discourse analysis, 85-103, Vienna: Passagen Verlag.

'DoD News Briefing-Secretary Rumsfeld and Gen. Myers' (2002), U.S. Department of Defence, available at http://www.defense.gov/transcripts/ (30 January, 2015).

Doran, Charles F. (1999), 'Why Forecasts Fail: The Limits and Potential of Forecasting in International Relations and Economics', International Studies Review 1(2): 11-41.

Drake, Frederic D. and Lynn R. Nelson (1999), eds., States' Rights and American Federalism: A Documentary History, Wesport: Greenwood.

Elias, Norbert (1978), The Civilizing Process, New York: Urizen Books.

Fabbrini, Sergio and Simona Piattoni, eds. (2007), Italy in the European Union: Redefining National Interest in a Compound Polity, Lanham: Rowman \& Littlefield Publishers.

Fabbrini, Sergio (2009), Compound Democracies: Why the United States and Europe Are Becoming Similar, Oxford: Oxford University Press.

Faust, Drew G. (1990), The Creation of Confederate Nationalism: Ideology and Identity in the Civil War South, Baton Rouge: Louisiana State University Press. 
Feeley, Malcolm and Edward Rubin (2011), Federalism: Political Identity and Tragic Compromise, Ann Arbor: University of Michigan Press.

Fransson, Niklas and Tommy Garling (1999), 'Environmental Concern: Conceptual Definitions, Measurement Methods and Research Findings', Journal of Environmental Psychology 19(4): 369-382.

Freeman, John R. and Brian L. Job (1979), 'Scientific forecast in international relations', International Studies Quarterly 23(1): 113-143.

Freedman, Lawrence (2009), 'Przyszłość studiów strategicznych’ in: Baylis, John, Withs James, Gray Collin, Cohen Eliot, eds. Strategia we współczenym świecie, Kraków: Wydawnictwo Uniwersytetu Jagiellońskiego.

Friedman, George (2009), The Next 100 Years, New York: Anchor Books.

Friedmam, Rebeca and Marcus Thiel, eds. (2012)European Identity and Culture: Narratives of Transnational Belonging, Farnham: Ashgate.

Gaddis, John Lewis (1992-1993), 'International Relations Theory and the End of the Cold War'. International Security, 17( 3,): 5-58.

Giddens, Anthony (1991), Modernity and Self-Identity: Self and Society in the Late Modern Age, Palo Alto: Stanford University Press.

Gilardi, Fabrizio (2012), 'Transnational diffusion: Norms, ideas, and policies', in Walter Carlsnaes, Thomas Risse and Beth Simmons, eds., Handbook of International Relations,453-477, Thousand Oaks: Sage Publications 2012.

Gilpin, Robert (1999), 'War and Change in World Politics', in Paul Viotti and Mark Kauppi, eds. International Relations Theory. Pluralism, Globalism and Beyond, Boston: Allyn and Bacon.

Glencross, Andrew (2009), What Makes the EU Viable? European Integration in the Light of the Antebellum US Experience, Basingstoke: Palgrave Macmillan.

Gould, Andrew C. and Anthony M. Messina, eds. (2014), Europe's Contending Identities: Supranationalism, Ethnoregionalism, Religion, and New Nationalism, Cambridge: Cambridge University Press 2014.

Grześkowiak, Alicja (2014), 'Assesment of Interpersonal Trust of Poles by the Principle Components Analysis and Log-Linear Modeling', Econometrics 1(43): 74-86.

Guzzini, Stefano (2000), 'A Reconstruction of Constructivism In International Relations', European Journal of International Relations 6(2): 147-182.

Halberstam, Daniel, and Mathias Reimann (2013), Federalism and Legal Unification: A Comparative Empirical Investigation of Twenty Systems, New York: Springer.

Hay, Colin (2002), Political Analysis: A Critical Introduction, Basingstoke: Palgrave Macmillan.

Heiss-Morse, Elisabeth (2009), Who Counts as an American? The Boundaries of National Identity, Cambridge: Cambridge University Press.

Herrmann, Richard K., Thomas Risse and Marilynn B. Brewer, eds. (2004), Transnational Identities: Becoming European in the EU, Lanham: Rowman \& Littlefield Publishers.

Hitlin, Steven, 'Values As the Core of Personal Identity: Drawing Links Between Two Theories of Self', Social Psychology Quarterly 66(2): 118-137

Homer, Pamela H. and Lynn R. Kahle (1988), 'A Structural Equation Test of the Value-Attitude-Behaviour Hierarchy', Journal of Personality and Social Psychology 54(4): 638646. 
Hopf, Ted (1998), 'The Promise of Constructivism in International Relations Theory', International Security 23(1): 171-200.

Hopf, Ted (2010), 'The logic of habit in International Relations', European Journal of International Relations 16(4): 539-561.

Jarvis, Darryl S.L. (2000), International Relations and the Challenge of Postmodernism. Defending the Discipline, Columbia: University of South Carolina Press.

Jones, Jeffrey J. (2014), 'Record-High 42\% of Americans Identify as Independents', Gallup. com, available athttp://www.gallup.com/poll (15 June, 2016).

Jonsson, Christer, Sven Tagil and Gunnar Tornqvist (2000), Organizing European Space, Thousand Oaks: Sage Publications.

Kaminski, John P. and Richard Lefler (1998), Federalists and Antifederalists: The Debate Over the Ratification of the Constitution, Lanham: Rowman \& Littlefield Publishers.

Kaplan, Morton A. (1966), 'The New Great Debate: Traditionalism vs. Science in International Relations',World Politics19(1): 1-20.

Karmis, Dimitrios and Wayne Norman (2005), Theories of Federalism: A Reader, Basingstoke: Palgrave Macmillan.

Keating, Joshua E. (2011), 'Megatrends that Weren't. A look at yesterday's Next Big Things, from the Japanese rising sun to Dow 36,000', Foreign Policy, (September/October).

Keulman, Kenneth and Anges K. Koos (2014), European Identity: Its Feasibility and Desirability, Lanham: Lexington Books.

Knight, Frank H. (1964), Risk, uncertainty and profit, New York: Sentery Press.

LaCroix, Alison L. (2011), The Ideological Origins of American Federalism, Cambridge, MA: Harvard University Press.

Lahire Bernard (2003), 'From the habitus to an individual heritage of dispositions. Towards a sociology at the level of the individual', Poetics, 31: 329-355.

Lasswell, Harold D. (1970), 'The Emerging Conception of the Policy Sciences', Policy Sciences, 1(1).

Lasswell, Harold D. (1971), A-Pre-View of Policy Sciences, New York: Elsevier.

Lee Ray, James (1998), 'Does Democracy cause Peace?' Annual Review of Political Science 1: $27-46$.

Lewis, Alan (2008), The Cambridge Handbook of Psychology and Economic Behaviour, Cambridge: Cambridge University Press 2006.

Maciag, Mike, 'Public Approval of State and Local Government Rises, Federal Rating Tumbles', Governing, available at http://www.governing.com/ (19 October, 2015).

Madison, James (1788), 'The Federalist No. 51. The Structure of the Government Must Furnish the Proper Checks and Balances Between the Different Departments', Independent Journal, (6 February, 1788).

Mazuri, Ali A. (1999), Progress" Illegitimate Child of Judeo-Christian Universalism and Western Ethnocentrism - A Third World Critique, in: Leo Marx, Bruce Mazlish, eds. Progress. Fact or Illusion?: The University of Michigan Press.

McCarthy, Justin (2014), 'Americans Still Trust Local Government More Than State', Gallup.com, available at http://www.gallup.com/poll (19 June, 2016).

McCourt, David, M. (2016) Practice Theory and Relationalism as the New Constructivism, "International Studies Quarterly", (60)

McGuire, Steven and Michael Smith (2008), The European Union and the United States: Convergence and Competition in the Global Arena, Basingstoke: Palgrave Macmillan. 
Merton, Robert K. (1968), Social Theory and Social Structure, New York: The Free Press. Mesquita, de Bruce B. (2010)., The Predictioneer's Game. Using the Logic of Brazen Self-Interest to See and Shape the Future, Ney York: Random House.

Meyer, Christoph O. (2011), 'The Purpose and Pitfalls of Constructivist Forecasting: Insights from Strategic Culture Research for the European Union's Evolution as a Military Power', International Studies Quarterly 55 (3): 669-690.

Milfont, Taciano L., John Duckitt and Claire Wagner (2010), A Cross-Cultural Test of the Value-Attitude-Behavior Hierarchy, Journal of Applied Social Psychology 40(11): 2791-2813.

Moran Dermont (2011), 'Edmund Husserl's Phenomenology of Habituality and Habitus', Journal of the British Society for Phenomenology, 42, (1): 53-77.

Müftüler-Bac, Meltem and Yannis A. Stivachtis, eds. (2008), Turkey-European Union relations: dilemmas, opportunities, and constraints, Lanham: Lexington Books.

National Research Council (2010), Persistent Forecasting of Disruptive Technologies, Washington D.C.: National Academic Press.

Norman, Wayne (2006), Negotiating Nationalism: Nation-Building, Federalism, and Secession in the Multinational State, Oxford: Oxford University Press.

Nugent, Neill (2010), The Government and Politics of the European Union, Basingstoke: Palgrave Macmillan.

Phelan, William (2012), 'What is Sui Generis about the European Union? Costly International Cooperation in a Self-Contained Regime', International Studies Review, 14(3): 367-385.

Pickel, Andreas (2005), 'The Habitus Process. A Biopsychosocial Conception', Journal for the Theory of Social Behaviour 35(4): 436-461.

'Public Trust in Government: 1958-2014' (2014),Pew Research Centre, available at http:// www.people-press.org/ (19 June 2016).

Reid, T.R. (2005), The United States of Europe: The New Superpower and the End of American Supremacy, London: Penguin Books.

Riley, Patrick (2006), 'The Social Contract and Its Critics' in Mark Goldie and Robert Wokler, eds. The Cambridge History of Eighteenth-Century Political Thought, 347-379 Cambridge: Cambridge University Press 2006.

Risse, Thomas (2010), A Community of Europeans? Transnational Identities and Public Spheres, Ithaca: Cornell University Press.

Schatz, Bettina (2014), How to Establish a Corporate Identity for the European Union: Development of a Brand Concept to create an "us-feeling" amongst European Citizens, Saarbrucken: AV Akademikerverlag.

Schlenker, Andrea (2013), 'Cosmopolitan Europeans or Partisans of Fortress Europe? Supranational Identity Patterns in the EU', Global Society 27(1): 25-51.

Schoutheete, Philippe de and Sami Andoura (2007), 'The Legal Personality of the European Union; Studia Diplomatica 60(1): 1-9.

Shim, Soyeon, Patti Warrington and Ellen Goldsberry (1999), A personal value-based model of college students' attitudes and expected choice behaviour regarding retailing careers, Family and Consumer Sciences Research Journal 28(1): 28-51.

Smith-Rosenberg, Carroll (2010), This Violent Empire: The Birth of an American National Identity, Chapel Hill: University of North Carolina Press. 
Stackelberg, Peter von Alex McDowell (2015), What in the World? Storyworlds, Science Fiction, and Futures Studies, Journal of Futures Studies 20(12): 47-65.

'State Governments Viewed Favorably as Federal Rating Hits New Low' (2013), Pew Research Centre, available athttp://www.people-press.org/ (19 June 2016).

Hechter, Michael, 'Symposium on Prediction in the Social Sciences' (1995), American Journal of Sociology 100(6): 1520-1527.

Tallberg, Jonas (2003), European Governance And Supranational Institutions: Making States Comply, London and New York: Routledge.

Tocqueville, Alexis de (1992), Democracy in America, London: Penguin Classics.

Trechsel, Alexander H. (2005), 'How to Federalize European Union... and Why Bother?', Journal of European Public Policy 12(3): 401-418.

Trubek, David M. and Thiery Bourgoignie (2013), eds. Consumer Law, Common Markets and Federalism in Europe and the United States, Berlin: Verlag De Gruyter-Recht.

University of California Television (UCTV), Conversations with History: Kenneth Waltz, https://www.youtube.com/watch?v=F9eV5gPlPZg\&t=1274s (visited: 21.05.2019).

Vaske, Jerry J. and Maureen P. Donnelly (1999), 'A value-attitude-behaviour model predicting wild land preservation voting intentions', Society and Natural Resources 12(6): 523-537.

Vertovec, Steven and Robin Cohen (2002), eds. Conceiving Cosmopolitanism: Theory, Context and Practice, New York: Oxford University Press.

Vincent, Jack E. (1980), 'Scientific Prediction versus Crystal Ball Gazing: Can the Unknown be Known?', International Studies Quarterly 24(3): 450-454.

Wacquant Loïc (2016), 'A concise genealogy and anatomy of habitus', The Sociological Review, 64: 64-72.

Waever, Ole (1996), The Rise and Fall of the Inter-paradigm Debate, in: Steve Smith, Ken Booth and Marysia Zalewski, eds. International Theory: Positivism \& Beyond,149-185, Cambridge: Cambridge University Press.

Wæver, Ole (1998), 'The Sociology of a Not So International Discipline: American and European Developments in International Relations', International Organization 52(4): 687-727.

Wendt, Alexander (1992), 'Anarchy is what States Make of it: The Social Construction of Power Politics', International Organization 46(2): 391-425.

Wendt, Alexander (1999), Social Theory of International Politics, Cambridge: Cambridge University Press.

Zimmerman, Joseph F. (2009), Contemporary American Federalism: The Growth of National Power, New York: State University of New York Press. 